\begin{tabular}{ll}
\hline \hline MINING AND METALLURGY INSTITUTE BOR & ISSN: 2334-8836 \\
& UDK: 622 \\
\hline \hline
\end{tabular}

UDK: $624.12 / .13: 550.8 \cdot 013: 519.249(045)=20$

DOI:10.5937/MMEB1304001D

Ksenija Đoković, Dragoslav Rakic ${ }^{* * *}$, Milenko Ljubojev ${ }^{* * * *}$

\title{
ESTIMATION OF SOIL COMPACTION PARAMETERS BASED ON THE ATTERBERG LIMITS ${ }^{* * *}$
}

\begin{abstract}
This paper presents the relationship between the Atterberg limits and soil compaction parameters obtained by the correlation- regression analysis. The relations between the liquid limit $w_{b}$ plastic limit $w_{p}$, maximum dry density $\rho_{\text {dmax }}$ and optimum moisture content $w_{\text {opt }}$ are obtained on the basis of the results of laboratory tests measured on a large number of samples of clay core earthfill dams Rovni, Selova, Prvonek and Barje. The regression and correlation analysis were obtained empirical equations and diagrams. Based on the obtained, the value of the optimum moisture content and maximum dry density of knowing the Atterberg limits of plasticity can be estimated.

Keywords: compaction parameters, maximum dry density, optimum moisture content, Atterberg limits, liquid limit, plastic limits, regression analysis
\end{abstract}

\section{INTRODUCTION}

When making earthfill dams, the earth embankments and some other earthen structures in general, basically the problem is to define conditions of embedding material, and optimum conditions of compaction. Embedding, i.e. suitability of materials for building in and behavior of materials during compaction depends on geomechanical properties of materials. Some materials, such as sandy gravel is easier to compact, while in clay, especially clay of high plasticity, it is

not [3]. Difficulties in the compaction of clayey material are closely related to the state of consistency index, where there is a dependency relationship of natural water content, plastic limit and liquid limits. This paper presents the relationship between the Atterberg limits $\left(w_{\mathrm{l}}, w_{\mathrm{p}}\right)$, plasticity index $\left(I_{p}\right)$ and soil compaction parameters $\left(\rho_{\mathrm{dmax}}\right.$ and $w_{\text {opt }}$ ) obtained by the standard laboratory tests (SRPS U.B1.020:1980, SRPS U.B1. 038:1997).

\footnotetext{
* IMS Institute, Belgrade, Bulevar vojvode Mišića; e-mail:ksenija.djokovic@institutims.rs ** University of Belgrade, Faculty of Mining and Geology, Djušina 7, 11000 Belgrade, Serbia **** Mining and Metallurgy Institute Bor, Zeleni bulevar 35, Bor, Serbia

***** The results shown in this paper are obtained as a part of the investigations conducted within the scope of the Project TR 36014 - Geotechnical Aspects of the Research and Development of Modern Technologies for the Construction and Rehabilitation of Municipal Solid Waste Landfills, funded by the Ministry of Education, Science and Technological Development of the Republic of Serbia.
} 
These dependencies were the subject of many previous studies. The first correlation relationship between the liquid limit, plastic limit and the optimum moisture content was established Jumikis (1946). Ring et al. (1962), in addition to the Atterberg limits in correlation, included the average particle diameter and percentage of fine grained particles [16]. Al - Khafaji (1993) gave a correlation equation for maximum dry density and optimum moisture content, based on liquid limits and plastic limits, for four sites in Iraq, compared to the correlation equations obtained for the soil in the U.S. (Ingles and Metcalf, 1972). In addition, he has developed the correlation diagrams that have a practical application in the estimation of compaction parameters [1]. Pandian et al. (1997) proposed a series of predicted curves of soil compaction using the liquid limit and plastic limits. They also gave the special equations for so-called wet and dry parts of the curve compaction [12]. Blotz et al. (1998) also proposed two equations for estimation the compaction parameters of soil using the liquid limit for different compaction effort: standard and modified [2]. Sridharan and Nagaraj (2005) proposed two empirical equations for estimation the parameters of compaction using only plastic limits [19]. In contrast to them, Matteo (2009) and Noor (2011) gave the predictive models for estimation the compaction parameters of fine grained soils for the Standard Proctor test, based on the plastic limit, plasticity index and specific gravity of soils $\rho_{s}[10,11]$. In recent years, in predicting the compaction parameters based on Atterberg limits, the method of artifical neural networks was used $[8,9]$.
In this paper, the relations between the liquid limit $w_{\mathrm{l}}$, the plastic limit $w_{\mathrm{p}}$, maximum dry density $\rho_{\text {dmax }}$ and optimum moisture content $w_{\text {opt }}$ are obtained on the basis of the results of laboratory tests measured on representative samples of clay from the core earthfill dams Rovni, Selova, Prvonek and Barje [4,5,6,7]. The correlation and regression analysis was applied to define the statistical model using MS Excel (Analysis ToolPak), where the empirical equations and diagrams were obtained.

As indicators of relationship degree, i.e. correlation between the analyzed variables, the followings were used: $r$ - coefficient of simple linear correlation (Pearson coefficient), $\mathrm{R}^{2}$ - coefficient of determination and $\mathrm{p}$ - value which expresses the statistical significance of correlation i.e. level of significance [13]. Although simple linear regression models were obtained with a significant value to the strong coefficient of correlation $(0.73<\mathrm{r}<0.85)$ and the coefficient of determination $\mathrm{R}^{2}\left(0.53<\mathrm{R}^{2}<073\right)$ and satisfying $\mathrm{p}$-value ( $\mathrm{p}<0.05)$, the analysis is extended using the multiple linear regression, the introduction of calculation at the same time both $w_{1}$ and $w_{\mathrm{p}}$.

\section{RESULTS OF GEOMECHANICAL LABORATORY TESTING}

Geotechnical laboratory testing of samples of clay were carried out during the geomechanical control of earthfill dams. Since a large number of samples, tested for statistical analysis, were selected, 72 representative samples were taken from the embedded core layer of earthfill dams in various stages of filling. 


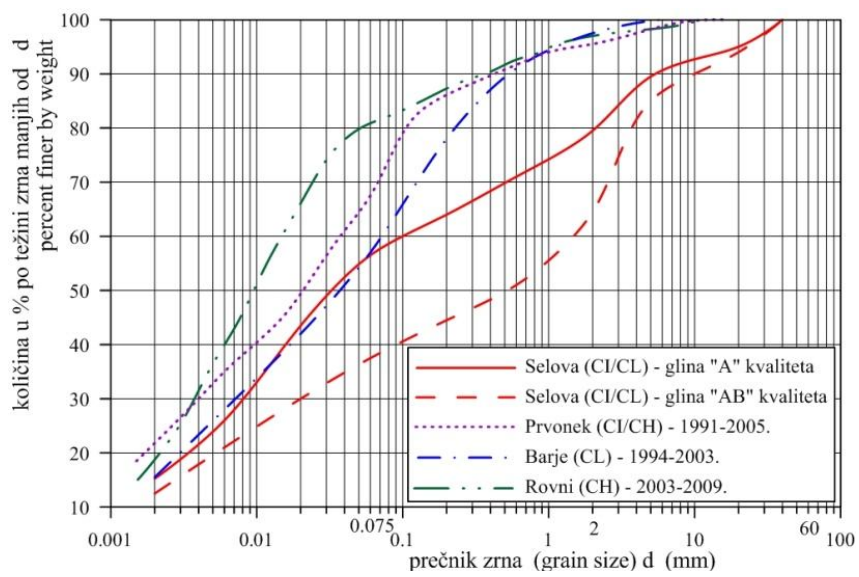

Figure 1 Average grain size distribution curves of tested clayey material

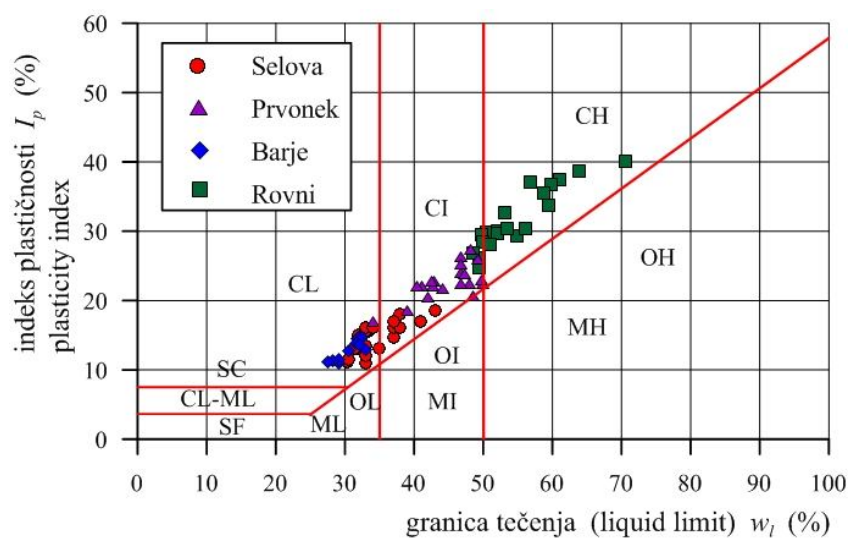

Figure 2 Diagram of plasticity the tested clayey material

Figure 1 shows the average particle size distribution curve, and Figure 2 shows a diagram of plasticity the tested materials from the clay core of earthfill dams Selova, Prvonek, Barje and Rovni.

According to the generally accepted classification of soil (SRPS U.B1. 001: 1990), based on the identification-classification experiments: the grain-size distribution and Atterberg limits of tested material present:

- Low plasticity sandy clays embedded in the core earthfill dam Barje - CL.

- Medium to high plasticity silty clay,
$\mathrm{CI} / \mathrm{CH}$, which originate from the core Prvonek earthfill dam,

- High plasticity silty clay $\mathrm{CH}$ from the core earthfill dam Rovni

- Clays embedded in the core earthfill dam Selova are sandy silty, medium to low plasticity CI-CL.

To determine maximum dry density and optimum moisture content of materials, the laboratory experiments were carried out by the standard Proctor compaction procedure (standard compaction energy $\mathrm{E}=592 \mathrm{~kJ} / \mathrm{m}^{3}$ ). The obtained results are shown in diagram in Figure 3. 


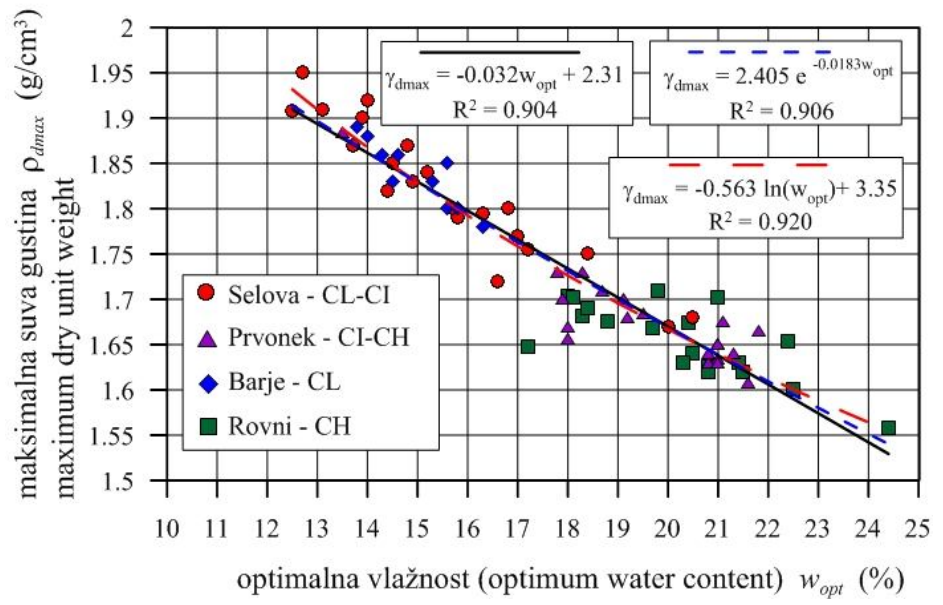

Figure 3 Diagram of relationship between maximum dry density and optimum moisture content of clayey soil

Furthermore, the mathematical relationship between $\rho_{\mathrm{dmax}}$ and $w_{\mathrm{opt}}$ is presented in Figure 3.

\section{STATISTICAL ANALYSIS AND DEFINING THE MODEL}

Regression analysis is statistical tool that is used to define the analytical - mathematical models, i.e. functions between the independent $(\mathrm{x})$ and dependent $(\mathrm{y})$ variables. Strength of dependence between variables is determined using the correlation analysis [13]. Discussion and interpretations model is based on the coefficient of correlation $r$ and coefficient of determination $\mathrm{R}^{2}$.

Value of coefficient of determination $\mathrm{R}^{2}$ indicates the representativeness of the model. The model is more representative of $\mathrm{R}^{2}$ which is closer to one. The linear coefficient of correlation $r$ is a measure of correlation strength between variables $\mathrm{x}$ and $\mathrm{y}$. According to Vukadinovic, if $r \leq 0: 30$ there was no significant correlation, if $0.5<\mathrm{r}<0.7$ correlation is significant, when $0.7<\mathrm{R}<0.9$ correlation is strong, in the case where $r>0.9$ very strong correlation [20]. So if the correlation coefficient was closer to one, the correlation was stronger.
The statistical significance of the model is defined using $\mathrm{p}$ - value or significance level $p$. If $p<0.05, p<0.01$ or $p<0.1$ is acceptable to the model and the safety of $\mathrm{P}>95 \%, \mathrm{P}>99 \%$, or P > 90\%. In the case where $p>0.05$ correlation was not significant, and then regardless of the value coefficient of correlation, a model should not be accepted and interpreted.

Although simple linear regression models, obtained (according to Vukadinovic, 1990) with the strong correlation coefficient values $(0.73<\mathrm{r}<0.85)$ and the coefficient of determination $R^{2}\left(0.53<R^{2}<073\right)$ and satisfying $p$-value $(p<0.05)$, the analysis is extended using the multiple linear regression.

According to the method of Multiple Linear Regression - MLR, the evaluation of required variable is obtained on the basis of simultaneous use of a number of other independent variables. As for the parameters of soil density (maximum dry density $\rho_{\mathrm{dmax}}$ and optimum moisture $\mathrm{w}_{\mathrm{opt}}$ ), six independent variables can be used in order to establish the most accurate according to their determination, as follows: E - energy compaction, $\mathrm{G}$ - percentage of gravel fractions, $\mathrm{S}$ - percentage of sand fraction, $\mathrm{SF}$ - percentage of 
fine fraction (clay and silt), $\mathrm{w}_{\mathrm{l}}$-liquid limit, $\mathrm{W}_{\mathrm{p}}$ - limits of plasticity and $I_{p}$ - plasticity index. According to Sivrakaya (2013), equation is as follows $[17,18]$.

$\left[\omega_{\text {opt }}, \rho_{\text {dmax }}\right]=f\left(E, G, S, F C, I_{p}, \omega_{i}, \omega_{p}\right)$

The work has also introduced into equation both liquid limit $\left(w_{1}\right)$ and plastic limits $\left(w_{\mathrm{p}}\right)$ simultaneously.

\section{The relationship between liquid limit and compaction parameters}

The first step analyzed the influence of $w_{1}$ (independent variable) on the compaction parameters $\rho_{\mathrm{dmax}}$ and $w_{\mathrm{opt}}$ as depen- dent variables. Where the following equations were obtained:

$$
\begin{aligned}
& \rho_{\text {dmax }}=2.088-0.008 w_{1} \\
& \mathrm{r}=0.85, \mathrm{R}^{2}=0.73, \mathrm{p}<0.05 \\
& w_{\text {opt }}=0.239 w_{\mathrm{l}}+7.757 \\
& \mathrm{r}=0.83, \mathrm{R}^{2}=0.69, \mathrm{p}<0.05
\end{aligned}
$$

Correlation between $\rho_{\mathrm{dmax}}$ and $w_{\mathrm{l}}$ is a negative linear correlation (Fig. 4a) with high coefficient of correlation $r$ and satisfactory $\mathrm{p}$-value $(\mathrm{p}<0.05)$.

Correlation between $w_{\text {opt }}$ and $w_{\mathrm{l}}$ is a positive linear correlation (Figure 4b) with slightly lower coefficient of correlation $r$, and satisfactory $\mathrm{p}$-value $(\mathrm{p}<0.05)$.

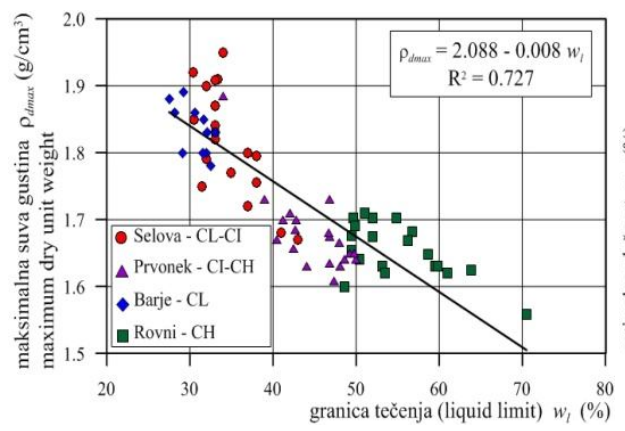

(a) $\rho_{\mathrm{dmax}}=f\left(w_{l}\right)$

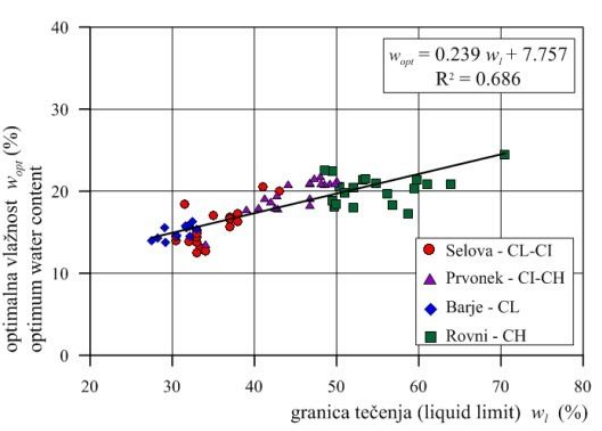

(b) $w_{\mathrm{opt}}=f\left(w_{l}\right)$

Figure 4 Diagrams of relationship between the liquid limit and compaction parameters

\section{The relationship between the plastic limit and compaction parameters}

The second step analyzes the influence of $w_{\mathrm{p}}$ (independent variable) on the compaction parameters $\rho_{\mathrm{dmax}}$ and $w_{\mathrm{opt}}$ as dependent variables. The following equations were obtained:

$$
\begin{aligned}
& \rho_{\text {dmax }}=2.229-0.023 w_{\mathrm{p}} \\
& \mathrm{r}=0.73, \mathrm{R}^{2}=0.53, \mathrm{p}<0.05 \\
& w_{\text {opt }}=0.742 w_{\mathrm{p}}+2.236 \\
& \mathrm{r}=0.78, \mathrm{R}^{2}=0.61, \mathrm{p}<0.05
\end{aligned}
$$

Correlation between $\rho_{\mathrm{dmax}}$ and $w_{\mathrm{p}}$ is a negative linear correlation (Fig. 5a) with a strong coefficient of correlation (Vukadinovic, 1990) and satisfactory p-value $(\mathrm{p}<0.05)$.

Correlation between $w_{\mathrm{opt}}$ and $w_{\mathrm{l}}$ is a positive linear correlation (Fig. 5b) with slightly higher coefficient of correlation, and satisfactory $\mathrm{p}$-value $\mathrm{p}<0.05$ ). 


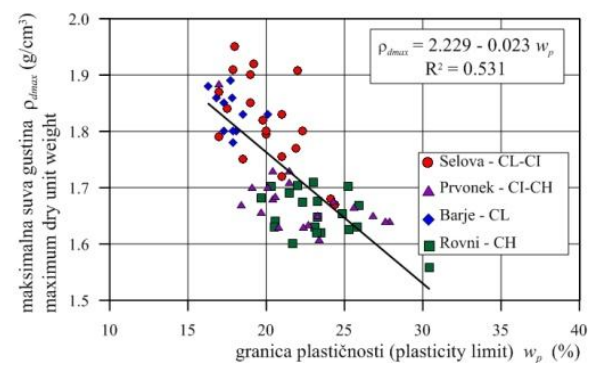

(a) $\rho_{\mathrm{dmax}}=f\left(w_{p}\right)$

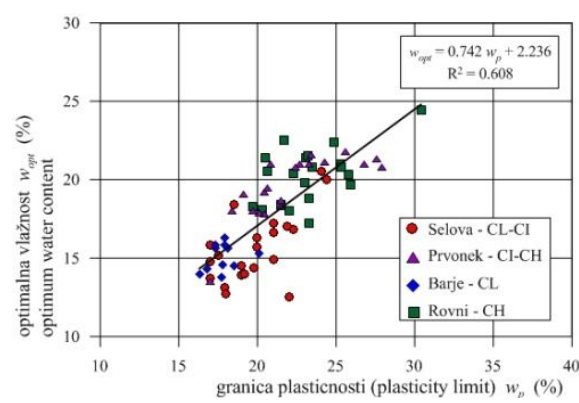

(b) $w_{\mathrm{opt}}=f\left(w_{p}\right)$

Figure 5 Diagrams of relationship between the plastic limit and compaction parameters

\section{The relationship between the plasticity index and compaction parameters}

The third step analyzes the influence of plasticity index $I_{p}$ (independent variable) on parameters of density $\rho$ dmax and $w_{\text {opt }}$ as dependent variables. As per definition, the plasticity index is the difference of liquid limit and plastic limit; it was interesting to analyze this effect. The following equations were obtained:

$$
\rho_{\mathrm{dmax}}=1.948-0.0099 I_{p}
$$

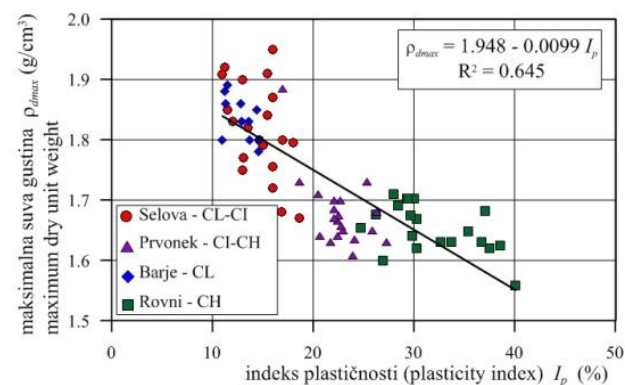

(a) $\rho_{\mathrm{dmax}}=f\left(I_{p}\right)$

$$
\begin{aligned}
& \mathrm{r}=0.78, \mathrm{R}^{2}=0.65, \mathrm{p}<0.05 \\
& w_{\text {opt }}=0.276 I_{p}+12.02 \\
& \mathrm{r}=0.73, \mathrm{R}^{2}=0.57, \mathrm{p}<0.05
\end{aligned}
$$

The relationship between $\rho_{\mathrm{dmax}}$ and $I_{p}$ is a negative linear correlation (Fig. 6a) with strong coefficient of correlation $r$ and satisfactory $\mathrm{p}$-value $(\mathrm{p}<0.05)$.

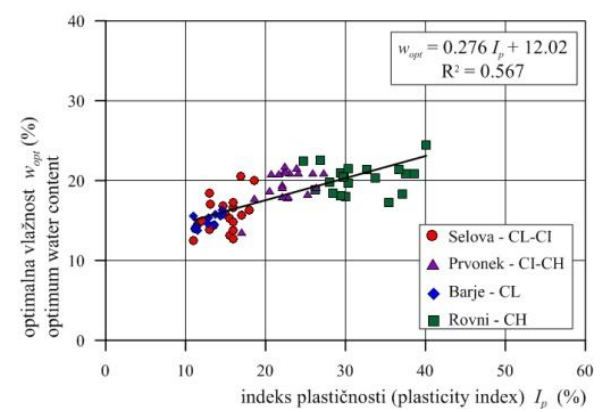

(b) $w_{\mathrm{opt}}=f\left(I_{p}\right)$

Figure 6 Diagrams of relationship between the plasticity index and compaction parameters

Correlation between $w_{\mathrm{opt}}$ and $I_{p}$ is a positive linear correlation (Fig. 6b) with strong coefficient of correlation $r$, and satisfactory $\mathrm{p}$-value $(\mathrm{p}<0.05)$.
In the fourth step, the analysis is extended using the method of multiple linear regression, introducing both $w_{\mathrm{l}}$ and $w_{\mathrm{p}} \mathrm{m}$ into equation. 


$$
\begin{aligned}
& \rho_{\text {dmax }}=2.14-0.007 w_{\mathrm{l}}-0.005 w_{\mathrm{p}} \\
& \mathrm{r}=0.86, \mathrm{R}^{2}=0.73, \mathrm{p}<0.05 \\
& w_{\text {opt }}=4.18+0.16 w_{\mathrm{l}}+0.323 w_{\mathrm{p}} \\
& \mathrm{r}=0,86, \mathrm{R}^{2}=0,73, \mathrm{p}<0,05
\end{aligned}
$$

The relation obtained for $\rho_{\text {dmax }}$ negative linear correlation with a strong coefficient of correlation $r=0.86$ and satisfactory p-value ( $\mathrm{p}<0.05)$.

Correlation obtained for $w_{\text {opt }}$ is a positive linear correlation with strong coefficient of correlation $r=0.86$, and satisfactory $\mathrm{p}$-value $(\mathrm{p}<0.05)$.

It is seen analyzing the obtained equations that optimum moisture increases until maximum dry density decreases with increasing plastic properties of the soil. The equation obtained for optimum moisture content $w_{\text {opt }}$ has stronger correlation with plastic limit $w_{\mathrm{p}}$, compared to the liquid limit $w_{1}$ and plasticity index $I_{p}$. However, the equations derived to calculate maximum dry density $\rho_{\text {dmax }}$ show stronger correlation relationship (higher coefficient of correlation) with the liquid limit $w_{1}$ and plasticity index $I_{p}$.

Model extended the application of the Multiple Linear Regression, introducing into the equation both $w_{1}$ and $w_{\mathrm{p}}$ giving the highest correlation coefficient $r=0.86$ and the coefficient of determination $\mathrm{R}^{2}=0.73$.

In addition to the linear regression, the logarithmic and exponential equations were also analyzed, but the best results with the highest coefficient of determination were given by linear equation. The linear correlation is far away from a practical point of view of the most acceptable.

\section{CONCLUSION}

Application of correlation - regression analysis was obtained by statistical models that define the relationship between the Atterberg limits: liquid limit $w_{1}$, the plastic limit $w_{\mathrm{p}}$, plasticity index $I_{p}$ and and soil compaction parameters: maximum dry density $\rho_{\mathrm{dmax}}$ and optimum moisture content $w_{\text {opt }}$. Statistical analysis was carried out at 72 representative sample derived from the core of the earth dams Rovni, Selova, Prvonek and Barje. The test materials are of low to high plastic clay. For the shown statistical models, there was strong linear correlation with strong coefficient of correlation $r$ and satisfactory $p$ value. As between the considered variables there are essential connections between (physical- mechanical properties of the soil), and analysis was carried out, the sufficient number of data were obtained with high degree of reliability on representative samples; the resulting models can be used to estimate the parameters compaction in the preliminary stages of the project, or preliminary assessment of suitability of any material from borrow pits controlling the quality of the earthfill structures.

\section{REFERENCES}

[1] Al-Khafaji A. N.: Estimation Soil Compaction Parameters by Means of Atterberg Limits, Quarterly Journal of Engineering Geologist, Vol. 26 (1993), pp.359-368;

[2] Blotz L. R., Benson C. H. dan Boutwell G. P: Estimating Optimum Water Content and Maximum Dry Unit Weight for Compacted Clay, Journal of Geotechnical and Geoenviromnental Engineering, Vol. 124 (1998), pp. 907-912;

[3] Djoković K., Šušić N., Čaki L., HadžiNiković G: Correlation between Parameters of Compaction and Grain Size Distribution of the Coarse Soils, Proceedings of the $15^{\text {th }}$ International Symposium of Macedonian Association of Structural Engineers, Struga, Macedonia, (2013), CT-5, pp.1-6;

[4] Detailed Studies on Control Geomechanical Testing the Materials Built 
into the Body of Embankment Dam «BARJE» during 1987-1990, Documentation of IMS Institute (in Serbian);

[5] Detailed Studies on Control Geomechanical Testing the Materials Built into the Body of Embankment Dam «SELOVA» during 1990-2006, Documentation of IMS Institute (in Serbian);

[6] Detailed Studies on Control Geomechanical Testing the Materials Built into the Body of Embankment Dam «PRVONEK» during 1994-2003, Documentation of IMS Institute (in Serbian);

[7] Detailed Studies on Control Geomechanical Testing the Materials Built into the Body of Embankment Dam «ROVNI» during 2003-2009, Documentation of IMS Institute (in Serbian);

[8] Gunaydin O. Estimation of Soil Compaction Parameters by Using Statistical Analyses and Artificial Neural Networks, Environ.Geol., Vol. 57 (2009), pp. 203-215;

[9] Isik F., Ozden G., Estimating Compaction Parameters of Fine and Coarsegrained Soils by Means of Artificial Neural Networks, Environ. Earth Sci. Vol.69 (2013), pp. 2287-2297;

[10] Matteo D. L., Bigotti F, Ricco R., Best-Fit Models to Estimate Modified Proctor Properties of Compacted Soil, Journal of Geotechnical and Geoenviromental Engiineering, ASCE, Vol. 135 (2009), pp. 992-996;

[11] Noor S., Chitra R, Gupta M., Estimation of Proctor Properties of Compacted Fine Grained Soils from Index and Physical Properties, International Journal of Earth Sciences and Engineering, Vol. 04, Iss. 06 SPL (2011), pp.147-150;
[12] Pandian N. S., Nagaraj T. S. and Manoj M. Re-examination of Compaction Characteristics of Fine Grained Soils. Geotechnique, Vol. 47, Iss. 2 (1997), pp. 363-366;

[13] Petz B, Basic Statistical Methods for Non Mathematicians, Zagreb: Naklada Slap, 1997, pp.180-233 (in Croatian);

[14] Rakić D., Čaki L., Ćorić S., Ljubojev M.: Residual Strength Parameters of High Plasticity Clay and Alevrites from Open/Pit Mine "Tamnava - West Field, Mining Enginerering No. 1 (2011), pp. 39-48;

[15] Rakić D., Šušić N., Ljubojev M.: Analysis of Foundation Settlement from Progressive Moistening of Silty Clay, Mining Enginerering No. 1 (2012), pp. 11-20;

[16] Ring G., Sallberg J., and Collins W. Correlation of Compaction and Classification Test Data, Hwy. Res. Bull. No. 325, Highway Research Board, National Research Council, Washington, D.C., (1962), pp. 55-75;

[17] Sivrakaya O., Kayadelen C., and Cecen E. Prediction of the Compaction Parameters for Coarse-grained Soils with Fines Content by MLR and GEP, Acta Geotechnica Slovenica, No. 2, (2013), pp. 29-41;

[18] Sivrakaya O., Togrol E., Kayadelen C: Estimating Compaction Behavior of Fine-grained Soils Based on Compaction Energy, Can. Geotechnical Journal, Vol. 45, (2008), pp. 877-887;

[19] Sridharan A. and Nagaraj, H. B., Plastic limit and Compaction Characteristics of Fine Grained Soils, Ground Improvement, Vol. 9, Iss. 1 (2005), pp. 17-22;

[20] Vukadinović S., Elements of Theory of Probability and Mathematical Statistics Privredni pregled, Belgrade, 1990 (in Serbian) 


\begin{tabular}{ll}
\hline \hline INSTITUT ZA RUDARSTVO I METALURGIJU BOR & ISSN: 2334-8836 \\
& UDK: 622 \\
\hline \hline
\end{tabular}

Ksenija Đokovic ${ }^{*}$, Dragoslav Rakic ${ }^{* *}$, Milenko Ljubojev ${ }^{* * *}$

\section{PROCENA PARAMETARA ZBIJANOSTI TLA NA OSNOVU ATTERBERGOVIH GRANICA KONZISTENCIJE}

\section{Izvod}

U radu je dat prikaz veze između Atterbergovih granica konzistencije i parametara zbijenosti tla dobijenih korelaciono-regresionom analizom. Veze između granice tečenja $w_{\mathfrak{b}}$, granice plastičnosti $w_{\mathrm{p}}$, maksimalne suve gustine $\rho_{\mathrm{dmax}} i$ optimalne vlažnosti $w_{\mathrm{opt}}$ su dobijene na osnovu rezultata laboratorijskih ispitivanja sprovedenim na velikom broju uzoraka iz glinenog jezgra nasutih brana: Rovni, Selova, Prvonek i Barje. Primenom regresione i korelacione analize dobijene su empirijske jednačine $i$ dijagrami. Na osnovu dobijenih jednačina moguće je proceniti vrednosti optimalne vlažnosti i maksimalne suve gustine poznavanjem Aterbergovih granica plastičnosti.

Ključne reči: parametri zbijenosti, maksimalna suva gustina, optimalna vlažnost, granica tečenja, granica plastičnosti, regresiona analiza

\section{UVOD}

Prilikom izrade nasutih brana, nasipa i nasutih objekata uopšte, osnovni problem predstavlja definisanje uslova ugrađivanja materijala, odnosno optimalnih uslova zbijanja. Ugradljivost tj. pogodnost materijala za ugradnju i ponašanje materijala prilikom zbijanja zavisi od geomehaničkih svojstava materijala. Pojedini materijali kao npr. peskoviti šljunkovi lakše se zbijaju, dok kod glina, posebno visokoplastičnih to nije slučaj [3]. Teškoće pri zbijanju glinovitih materijala usko su vezane za stanje konzistencije, pri čemu postoji zavisnost odnosa i prirodne vlažnosti, granice plastičnosti granice tečenja. U radu je dat prikaz zavisnosti između Atterbergovih granica konzistencije $\left(w_{\mathrm{l}}, w_{\mathrm{p}}\right)$, indeksa plastičnosti $\left(I_{p}\right)$ i parametara zbijenosti tla $\left(\rho_{\mathrm{dmax}} \mathrm{i} w_{\mathrm{opt}}\right)$, dobijenih standardnim laboratorijskim opitima (SRPS U.B1.020:1980, SRPS U.B1. 038:1997).

Ove zavisnosti bile su predmet mnogih ranijih istraživanja. Prvu korelacionu zavisnost između granice tečenja, granice plastičnosti i optimalne vlažnosti, uspostavio je Jumikis (1946). Ring i dr. (1962) su pored

\footnotetext{
*Institut IMS, Beograd, Bulevar vojvode Mišića 43; e-mail: ksenija.djokovic@institutims.rs ** Univerzitet u Beogradu, Rudarsko-geološki fakultet, Beograd, Đušina 7

*** Institut za rudarstvo i metalurgiju Bor, Zeleni bulevar 35, Bor, Srbija

${ }^{* * * * *}$ U radu su prikazani rezultati koji su deo istraživanja na projektu TR 36014 - Geotehnički aspekti istraživanja i razvoja savremenih tehnologija građenja i sanacija deponija komunalnog otpada, koje finansira Ministarstvo prosvete, nauke i tehnološkog razvoja R. Srbije.
} 
Aterbergovih granica konzistencije u korelaciju uključili i prosečnu veličinu (prečnik i procentualno učešće finozrnih čestica [16]. Al-Khafaji (1993) je dao jednačine korelacije za maksimalnu suvu gustinu i optimalnu vlažnost na osnovu granice tečenja i granice plastičnosti, za četiri lokacije $u$ Iraku, poredivši ih sa korelacionim jednačinama koje su dobijene za tla u SAD (Ingles i Metcalf 1972). Pored toga, on je izradio i dijagrame zavisnosti koji imaju svoju praktičnu primenu prilikom procene parametara zbijenosti [1]. Pandian i dr. (1997) su predložili procenu zbijenosti tla preko serija krivih na osnovu granice tečenja i granice plastičnosti. Takođe, su dali i posebne jednačine za tzv. mokri i suvi deo krive zbijenosti [12]. Blotz i dr.(1998) su predložili dve jednačine za procenu parametara zbijenosti tla na osnovu granice tečenja ali za različite energije zbijanja: standardnu i modifikovanu [2]. Sridharan i Nagaraj (2005) su predložili dve empirijske jednačine za procenu parametara zbijanja korišćenjem samo granice plastičnosti [19]. Za razliku od njih, Matteo (2009) i Noor (2011) su dali korelacione modele procene parametara zbijenosti za sitnozrna tla za standardni Proctorov opit na osnovu granice plastičnosti, indeksa plastičnosti i gustine čvrstih čestica tla $\left(\rho_{\mathrm{s}}\right)[10,11]$. Poslednjih godina za uspostavljanje zavisnosti Aterbergovih granica konzistencije i parametara zbijenosti tla koriste se neuronske mreže $[8,9]$.

$\mathrm{U}$ ovome radu veze između granice tečenja $w_{\mathrm{l}}$, granice plastičnosti $w_{\mathrm{p}}$, indeksa plastičnosti $I_{p}$ i maksimalne suve gustine $\rho_{\text {dmax }}$ i optimalne vlažnosti $w_{\text {opt }}$, su dobijene na osnovu rezultata laboratorijskih ispiti- vanja sprovedenim na reprezentativnim uzorcima gline iz jegra nasutih brana: Rovni, Selova, Prvonek i Barje [4,5,6,7]. Za definisanje statističkog modela primenjena je korelaciono - regresiona analiza sprovedena pomoću MS Excel programa (Analysis ToolPak) pri čemu su dobijene empirijske jednačine i dijagrami.

Kao pokazatelji stepena zavisnosti korelacije između analiziranih promenljivih korišćeni su: $r$ - koeficijent proste linearne korelacije (Pearsonov koeficijent), $\mathrm{R}^{2}$ - koeficijent determinacije i p - statistička značajnost korelacije odnosno prag značajnosti [13]. Iako su prostom linearnom regresijom dobijeni modeli sa značajnim vrednostima koeficijenta korelacije $\mathrm{r}(0,73<\mathrm{r}<0,85)$ i koeficijenta determinacije $\mathrm{R}^{2}\left(0,53<\mathrm{R}^{2}<\right.$ $0,73)$ i zadovoljavajućim pragom značajnosti p ( $\mathrm{p}<0,05)$, analiza je proširena metodom višestruke linearne regresije, uvođenjem u proračun istovremeno i granicu tečenje $w_{\mathrm{l}}$ i granicu plastičnosti $w_{\mathrm{p}}$.

\section{REZULTATI LABORATORIJSKIH GEOMEHANIČKIH ISPITIVANJA}

Laboratorijska geomehanička ispitivanja uzoraka gline vršena su prilikom geomehaničke kontrole nasutih brana. Od velikog broja ispitanih uzoraka za statističku analizu je odabrano 72 uzorka koji predstavljaju reprezentativne uzorke uzete iz ugrađenih slojeva jezgra nasutih brana za različite faze nasipanja.

Na slici 1. su prikazane prosečne krive granulometrijskog sastava, a na slici 2 . dijagram plastičnosti za ispitivane materijale glinenog jezga nasutih brana: Selova, Prvonek, Barje i Rovni. 


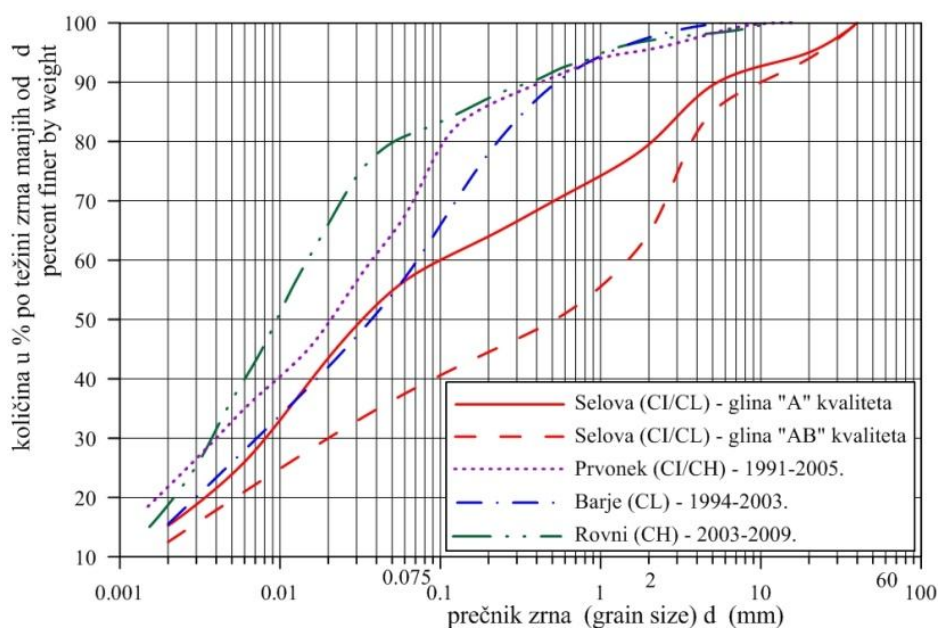

Sl. 1. Prosečne granulometrijske krive ispitivanih glinovitih materijala

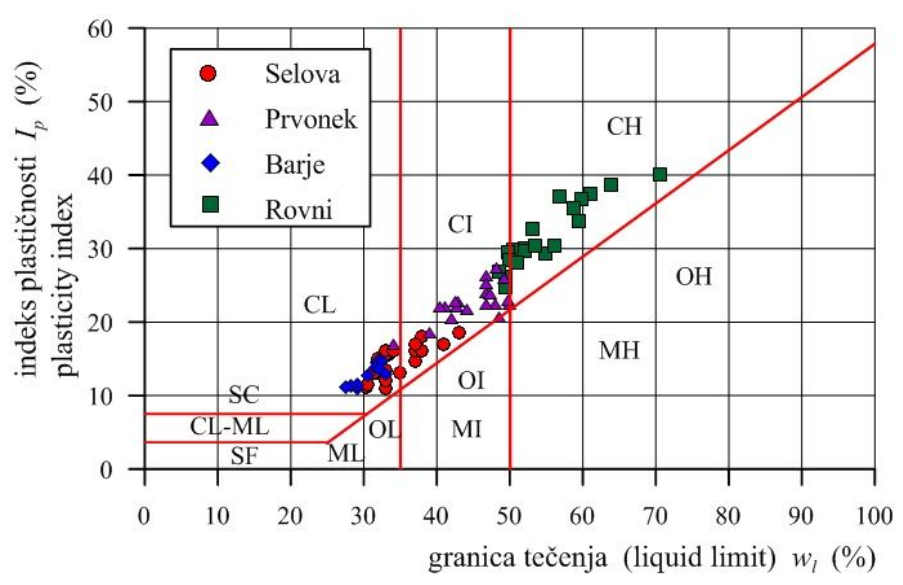

Sl. 2. Dijagram plastičnosti ispitivanih glinovitih materijala

Prema opštoj klasifikacija tla (SRPS U.B1.001:1990), a na osnovu identifikaciono-klasifikacionih opita: granulometrijskog sastava i Atterbergovih granica konzistencije, ispitivani materijali predstavljaju:

- niskoplastične peskovite gline ugrađene $\mathrm{u}$ jezgro nasute brane Barje CL,

- srednje do visokoplastične prašinaste gline CI-CH koje potiču iz jezgra nasute brane Prvonek,
- visokoplastične gline $\mathrm{CH}$ iz jezgra nasute brane Rovni,

- gline ugrađene u jezgro nasute brane Selova su peskovito prašinaste, srednje do niske plastičnosti CI-CL.

Za određivanje maksimalne suve gustine i optimalne vlažnosti ugrađenih materijala, urađeni su laboratorijski opiti zbijanja po standardnom Proctor-ovom postupku (standardna energija zbijanja $\mathrm{E}=592$ $\mathrm{kJ} / \mathrm{m}^{3}$ ). Dobijeni rezultati su prikazani na dijagramu na slici 3 . 


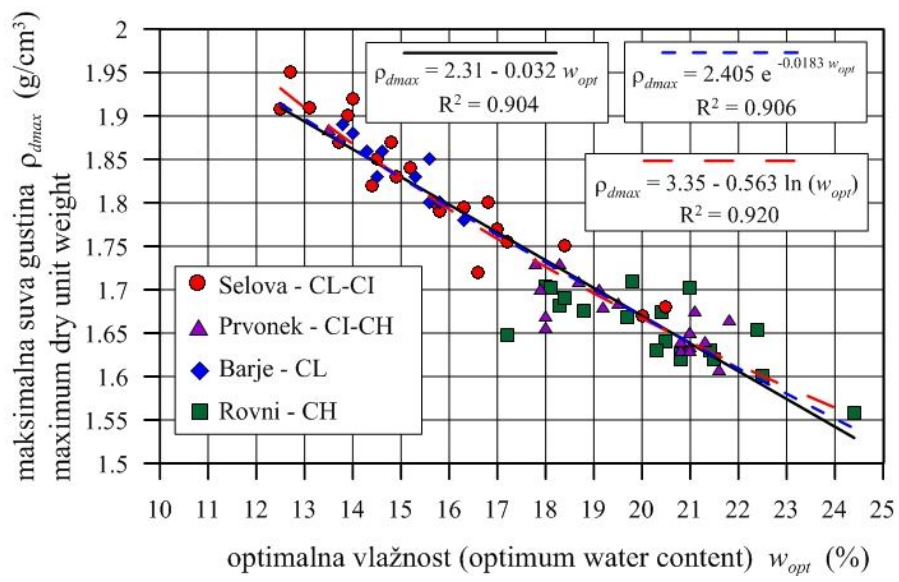

SI. 3. Dijagram zavisnosti maksimalne suve gustine i optimalne vlažnosti glinovitih tla

Pored toga, na slici 3. prikazana je i matematičkih zavisnosti između $\rho_{\mathrm{dmax}} \mathrm{i} w_{\mathrm{opt}}$.

\section{STATISTIČKA ANALIZA I DEFINISANJE MODELA}

Regresiona analiza je statistički alat koji se koristi za definisanje analitičko-matematičkog modela tj. funkcije između nezavisnih (x) i zavisnih (y) promenljivih. Jačina zavisnosti između promenljivih određuje se korelacionom analizom [13]. Diskusija i interpretacija modela zasniva se na koeficijentu korelacije $r$ i koeficijentu determinacije $\mathrm{R}^{2}$.

Veličina koeficijenta determinacije $\mathrm{R}^{2}$ govori o reprezentativnosti modela. Model je reprezentativniji što je $R^{2}$ bliže jedinici. Koeficijent linearne korelacije $r$ je mera jačine korelacije između promenljivih $\mathrm{x}$ i $\mathrm{y}$. Prema Vukadinoviću ukoliko je $\mathrm{r} \leq 0,30$ nema značajne korelacije, ako je $0,5<\mathrm{r}$ $<0,7$ korelacija je značajna, kada je $0,7<\mathrm{r}$ $<0,9$ korelacija je jaka, a u slučaju kada je r > 0,9 vrlo jaka korelacija [20]. Dakle, što je koeficijent korelacije bliži jedinici korelaciona veza je jača.

Statistička značajnost modela definiše se pragom značajnosti p. Ukoliko je p < 0,05, $\mathrm{p}<0,01$ ili $\mathrm{p}<0,1$ model je prihvatljiv sa $\mathrm{i}$ sigurnošću od P > 95\%, P > 99\% ili $\mathrm{P}>$ $90 \%$. U ovoj analizi usvojen je prag značajnosti od p < 0,05. U slučaju kada je p > 0,05 korelacija nije značajna $i$ tada se bez obzira na vrednost koeficijenta korelacije model ne sme prihvatiti i tumačiti.

Iako su prostom linearnom regresijom dobijeni modeli (prema Vukadinoviću, 1990) sa jakim vrednostima koeficijenta korelacije $r \quad(0,73<r<0,85)$ i koeficijenta determinacije $\mathrm{R}^{2}(0,53<\mathrm{R}<0,73)$ i zadovoljavajućim pragom značajnosti $\mathrm{p}(\mathrm{p}<0,05)$, analiza je proširena primenom metode višestruke linearne regresije.

Prema metodi višestruke linearne regresije - MLR (Multiple Linear Regression) procena tražene promenljive dobija se na osnovu istovremenog korišćenja nekoliko drugih varijabilnih promenljivih. Kada su u pitanju parametri zbijenosti tla (maksimalna suva gustina $\rho_{\mathrm{dmax}} \mathrm{i}$ optimalna vlažnost $w_{\text {opt }}$ ), može se koristi sedam nezavisnih promenljivih kako bi se uspostavile najpreciznije zavisnosti za njihovo određivanje, i to: E - energija zbijanja, G - procentualno učešće šljunkovitih frakcija, S - procentualno učešce peskovitih frakcija, SF - procentualni sadržaj finih frakcija (gline i prašine), $w_{1}$ granica tečenja, $w_{\mathrm{p}}$ - granica plastičnosti i $I_{p}$ 
- indeks plastičnosti. Prema Sivrakaya-u (2013) jednačina glasi $[17,18]$.

$\left[\omega_{\text {opt }}, \rho_{\text {dmax }}\right]=f\left(E, G, S, F C, I_{p}, \omega_{i}, \omega_{p}\right)$

U radu su istovremeno u jednačinu uvedene granica tečenja $\left(w_{1}\right)$ i granica plastičnosti $\left(w_{\mathrm{p}}\right)$.

\section{Zavisnost između granice tečenja $i$ parametara zbijenosti}

U prvom koraku analiziran je uticaj $w_{\mathrm{I}}$ (nezavisna promenljiva) na parametre zbijenosti $\rho_{\mathrm{dmax}} \mathrm{i} w_{\mathrm{opt}}$ kao zavisnih promenljivih. Pri čemu su dobijene jednačine:

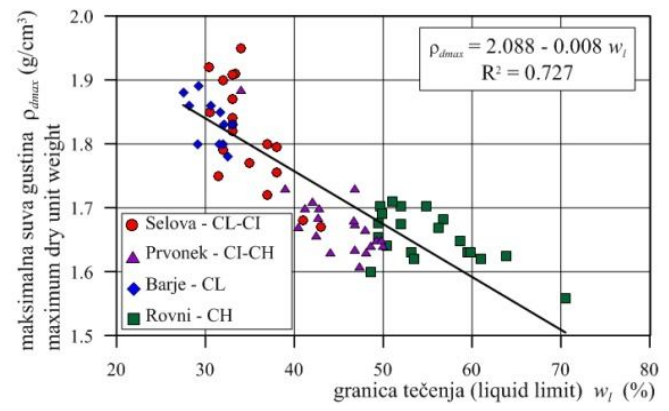

(a) $\rho_{\mathrm{d} \max }=f\left(w_{l}\right)$

$$
\begin{aligned}
& \rho_{\mathrm{d} \max }=2.088-0.008 w_{\mathrm{l}} \\
& \mathrm{r}=0.85, \mathrm{R}^{2}=0.73, \mathrm{p}<0.05
\end{aligned}
$$

$$
\begin{aligned}
& w_{\text {opt }}=0.239 w_{\mathrm{l}}+7.757 \\
& \mathrm{r}=0.83, \mathrm{R}^{2}=0.69, \mathrm{p}<0.05
\end{aligned}
$$

Korelacija između $\rho_{\text {dmax }}$ i $w_{1}$ je negativna linearna korelacija (Slika 4a) sa visokim koeficijentom korelacije $\mathrm{r}$ i zadovoljavajućim pragom značajnosti $(\mathrm{p}<0.05)$.

Korelacija između $w_{\text {opt }}$ i $w_{1}$ je pozitivna linearna korelacija (Slika 4b) sa neznatno nižim koeficijentom korelacije $r$, i zadovoljavajućim pragom značajnosti $(\mathrm{p}<0.05)$.

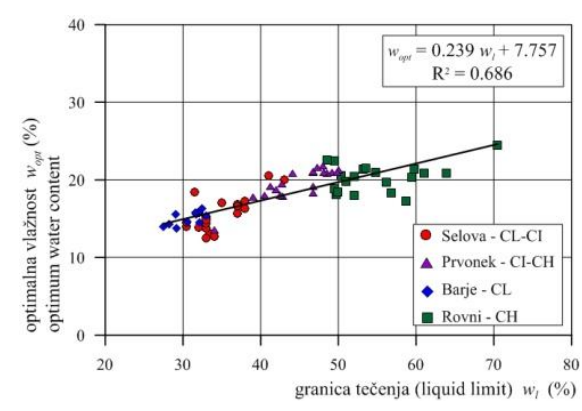

(b) $w_{\mathrm{opt}}=f\left(w_{l}\right)$

Sl. 4. Dijagrami zavisnost između granice tečenja i parametara zbijenosti

\section{Zavisnost između granice plastičnosti i parametara zbijenosti}

$\mathrm{U}$ drugom koraku analiziran je uticaj $w_{\mathrm{p}}$ (nezavisna promenljiva) na parametre zbijenosti $\rho_{\mathrm{dmax}}$ i $w_{\mathrm{opt}}$ kao zavisnih promenljivih. Pri čemu su dobijene jednačine:

$$
\begin{aligned}
& \rho_{\text {dmax }}=2.229-0.023 w_{\mathrm{p}} \\
& \mathrm{r}=0.73, \mathrm{R}^{2}=0.53, \mathrm{p}<0.05 \\
& w_{\text {opt }}=0.742 w_{\mathrm{p}}+2.236 \\
& \mathrm{r}=0.78, \mathrm{R}^{2}=0.61, \mathrm{p}<0.05
\end{aligned}
$$

Korelacija između $\rho_{\mathrm{dmax}} \mathrm{i} w_{\mathrm{p}}$ je negativna linearna korelacija (Slika 5a) sa jakim koeficijentom korelacije (Vukadinović, 1990) i zadovoljavajućim pragom značajnosti $(\mathrm{p}<$ $0,05)$.

Korelacija između $w_{\text {opt }}$ i $w_{1}$ je pozitivna linerana korelacija (Slika 5b) sa neznatno višim koeficijentom korelacije, i zadovoljavajućim pragom značajnosti $(\mathrm{p}<0.05)$. 


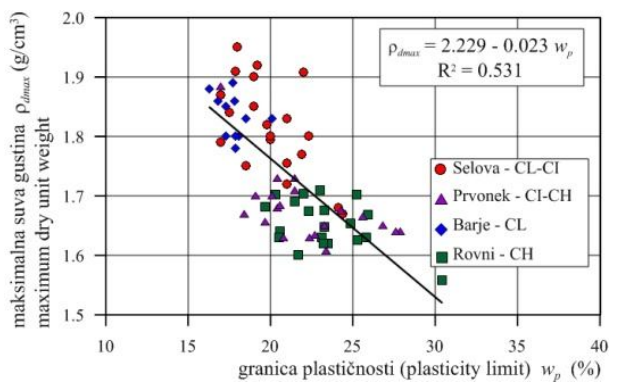

(a) $\rho_{\mathrm{dmax}}=f\left(w_{p}\right)$

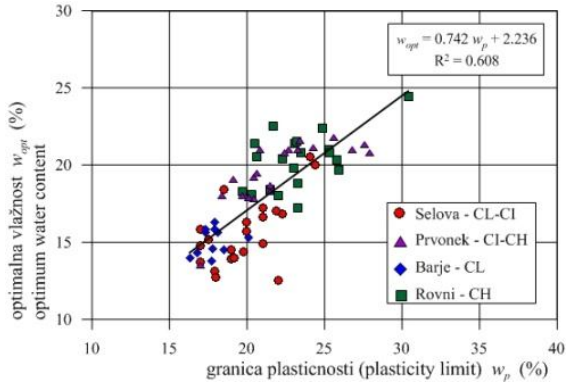

(b) $w_{\mathrm{opt}}=f\left(w_{p}\right)$

Sl. 5. Dijagrami zavisnost između granice plastičnosti i parametara zbijenosti

\section{Zavisnost između indeksa plastičnosti i parametara zbijenosti}

U trećem koraku analiziran je uticaj $I_{p}$ (nezavisna promenljiva) na parametre zbijenosti $\rho_{\text {dmax }}$ i $w_{\text {opt }}$ kao zavisne promenljive. Kako po definiciji indeks plastičnosti predstavlja razliku granice tečenje i granice plastičnosti bilo je interesantno analizirati i ovaj uticaj. Dobijene su sledeće jednačine:

$$
\rho_{\mathrm{dmax}}=1.948-0.0099 I_{p}
$$

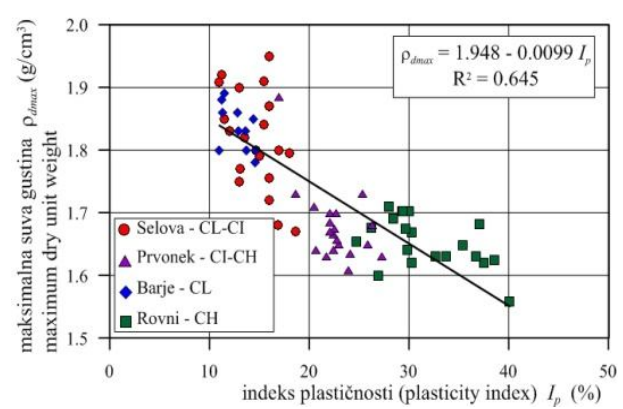

(a) $\rho_{\mathrm{dmax}}=f\left(I_{p}\right)$

$$
\begin{aligned}
& \mathrm{r}=0.78, \mathrm{R}^{2}=0.65, \mathrm{p}<0.05 \\
& w_{\text {opt }}=0.276 I_{p}+12.02 \\
& \mathrm{r}=0.73, \mathrm{R}^{2}=0.57, \mathrm{p}<0.05
\end{aligned}
$$

Relacija između $\rho_{\text {dmax }}$ i $I_{p}$ je negativna linearna korelacija (Slika 6a) sa jakim koeficijentom korelacije i zadovoljavajućim pragom značajnosti $(\mathrm{p}<0.05)$.

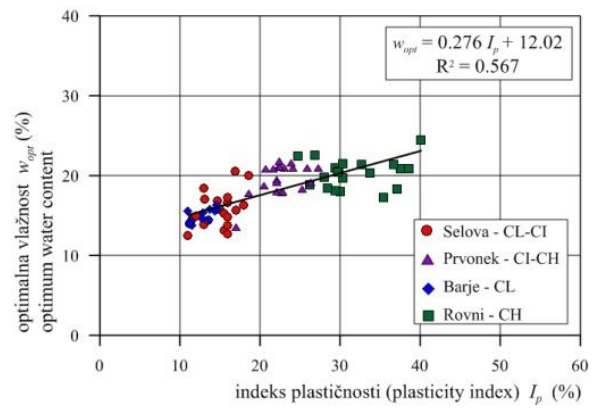

(b) $w_{\mathrm{opt}}=f\left(I_{p}\right)$

Sl. 6. Dijagrami zavisnost između indeksa plastičnosti i parametara zbijenosti

Korelacija između $w_{\text {opt }}$ i $I_{p}$ je pozitivna linearna korelacija (Slika 6b) sa jakim koeficijentom korelacije, i zadovoljavajućim pragom značajnosti $(\mathrm{p}<0.05)$.

$\mathrm{U}$ četvrtom koraku analiza je proširena primenom metode višestruke linearne regre- sije, uvođenjem u jednačinu istovremeno i granice tečenja $w_{1}$ i granice plastičnosti $w_{\mathrm{p}}$.

$$
\begin{aligned}
& \rho_{\mathrm{dmax}}=2.14-0.007 w_{\mathrm{l}}-0.005 w_{\mathrm{p}} \\
& \mathrm{r}=0.86, \mathrm{R}^{2}=0.73, \mathrm{p}<0.05
\end{aligned}
$$




$$
\begin{aligned}
& w_{\text {opt }}=4.18+0.16 w_{\mathrm{l}}+0.323 w_{\mathrm{p}} \\
& \mathrm{r}=0,86, \mathrm{R}^{2}=0,73, \mathrm{p}<0,05
\end{aligned}
$$

Relacija dobijena za $\rho_{\text {dmax }}$ je negativna linearna korelacija sa jakim koeficijentom korelacije $\mathrm{r}=0,86 \mathrm{i}$ zadovoljavajućim pragom značajnosti $(p<0,05)$.

Korelacija dobijena za $w_{\text {opt }}$ je pozitivna linearna korelacija sa jakim koeficijentom korelacije $r=0,86$, i zadovoljavajućim pragom značajnosti $(p<0,05)$.

Analizom dobijenih jednačina uočavamo da optimalna vlažnost raste dok maksimalna suva gustina se smanjuje sa porastom plastičnih svojstava tla. Jednačina dobijena za optimalnu vlažnost $w_{\text {opt }}$ ima jaču korelaciju sa granicom plastičnosti $w_{\mathrm{p}} \mathrm{u}$ poređenju sa granicom tečenja $w_{1} \mathrm{i}$ indeksom plastičnosti $I_{p}$. Međutim, jednačine dobijene za izračunavanje maksimalne suve gustine $\rho_{\text {dmax }}$, pokazuju jaču korelacionu vezu (viši koeficijen korelacije) sa granicom tečenja $w_{1}$ $\mathrm{i}$ indeksom plastičnosti $I_{p}$.

Model proširena primenom metode višestruke linearne regresije, uvođenjem $u$ jednačinu istovremeno $\mathrm{i} w_{1}$ i $w_{\mathrm{p}}$ daje najviši koeficijent korelacije $\mathrm{r}=0,86 \mathrm{i}$ koeficijent determinacije $\mathrm{R}^{2}=0,73$.

Pored linearne regresije analizirane su još i logaritamska i eksponencijalna jednačina, ali je daleko najbolje rezultate sa najvećim koeficijentom determinacije dala linearna jednačina. S obzirom na to, a i zbog praktičnih razloga, može se reći da je linearna zavisnost najprihvatljivija.

\section{ZAKLJUČAK}

Primenom korelaciono - regresione analize dobijeni su statistički modeli kojima se definiše zavisnost između Atterbergovih granica konzistencije: granice plastičnosti $w_{\mathrm{l}}$, granice tečenja $w_{\mathrm{p}}$, indeksa plastičnosti $I_{p}$ i parametara zbijnosti tla: optimalne vlažnosti $w_{\text {opt }}$ i maksimalne suve gustine $\rho_{\text {dmax }}$. Statistička analiza sprovedena je na ukupno 72 reprezenativna uzorka koji potiču iz jezgra nasutih brana: Rovni, Selova, Prvonek i Barje. Ispitivani mate- rijali predstavljaju nisko do visoko plastične gline. Za prikazane statističke modele postoji jaka linearna korelaciona veza sa jakim koeficijentom korelacije $r$ i zadovoljavajućim pragom značajnosti p. Kako između razmatranih promenljivih postoji i suštinska poveznost (fizičko-mehanička svojstva tla), i analiza je sprovedena na dovoljnom broju podataka koji su dobijeni sa visokim stepenom pouzdanosti na reprezentativnim uzorcima, dobijeni modeli se mogu primenjivati za procenu parametara zbijenosti u fazama idejnog projekta, ili za preliminarnu procenu pogodnosti materijala za nasipanje iz pozajmišta, kod kontrolisanja kvaliteta na nasutim objektima.

\section{LITERATURA}

[1] Al-Khafaji A.N: Estimation Soil Compaction Parameters by Means of Atterberg Limits, Quarterly Journal of Engineering Geologist, Vol. 26 (1993), str.359-368.

[2] Blotz, L. R., Benson C. H. dan Boutwell G. P: Estimating Optimum Water Content And Maximum Dry Unit Weight For Compacted Clay, Journal of Geotechnical and Geoenviromnental Engineering, Vol. 124 (1998), str. 907-912.

[3] Đoković K., Šušić N., Čaki L.,HadžiNiković G: Correlation Between Parameters of Compaction and Grain Size Distribution of the Coarse Soils, Proceedings of $15^{\text {th }}$ International Symposium Macedonian Association of Structural Engineers, Struga, Macedonia, (2013), CT-5, str. 1-6.

[4] Elaborati o kontrolnim geomehaničkim ispitivanjima materijala ugrađenih $\mathrm{u}$ telo nasute brane «BARJE» $\mathrm{u}$ toku 1987-1990. godine, Dokumentacija Instituta IMS.

[5] Elaborati o kontrolnim geomehaničkim ispitivanjima materijala ugrađenih $\mathrm{u}$ telo nasute brane «SELOVA» $\mathrm{u}$ toku 
1990-2006. godine, Dokumentacija Instituta IMS.

[6] Elaborati o kontrolnim geomehaničkim ispitivanjima materijala ugrađenih $\mathrm{u}$ telo nasute brane «PRVONEK» $\mathrm{u}$ toku 1994-2003. godine, Dokumentacija Instituta IMS.

[7] Elaborati o kontrolnim geomehaničkim ispitivanjima materijala ugrađenih $\mathrm{u}$ telo nasute brane «ROVNI» $\mathrm{u}$ toku 2003-2009. godine, Dokumentacija Instituta IMS

[8] Gunaydin O: Estimation of Soil Compaction Parameters by Using Statistical Analyses and Artifical Neural Networks, Environ. Geol., Vol. 57 (2009), str. 203-215.

[9] Isik F., Ozden G: Estimating Compaction Parameters of Fine and Coarse-grained Soils by Means of Atrificial Neural Networks, Environ. Earth Sci., Vol. 69 (2013), str. 2287 2297.

[10] Matteo D. L., Bigotti F, Ricco R.: Best-Fit Models to Estimate Modified Proctor Properties of Compacted Soil, Journal of Geotechnical and Geoenviromental Engiineering, ASCE, Vol. 135 (2009), str. 992-996.

[11] Noor S., Chitra R, Gupta M: Estimation of Proctor Properties of Compacted Fine Grained Soils from Index and Physical Properties, International Journal of Earth Sciences and Engineering, Vol. 04, Iss. 06 SPL (2011), str. 147-150.

[12] Pandian N. S., Nagaraj T. S. and Manoj M.: Re-examination of Compaction Characteristics Offine Grained Soils, Geotechnique, Vol. 47, Iss. 2 (1997), str. 363-366.
[13] Petz B, Osnovne statističke metode za nemamematičare, Zagreb: Naklada Slap, 1997, str. 180-233.

[14] Rakić D., Čaki L., Ćorić S., Ljubojev M: Rezidualni parametri čvrstoće smicanja visokoplastičnih glina $\mathrm{i}$ alevrita PK „Tamnava - Zapadno Polje“, Rudarski radovi, Institut za rudarstvo i metalurgiju Bor, 1 (2011), str. 29-38.

[15] Rakić D., Šušić N., Ljubojev M.: Analiza sleganja temelja usled progresivnog provlažavanja prašinastih glina, Rudarski radovi, Institut za rudarstvo i metalurgiju Bor, 1 (2012), str. 1-10.

[16] Ring G., Sallberg J., and Collins W.: Correlation of Compaction and Classification Test Data, Hwy. Res. Bull. No. 325, Highway Research Board, National Research Council, Washington, D.C., (1962), str. 55-75.

[17] Sivrakaya O., Kayadelen C., and Cecen E.: Prediction of the Compaction Parameters for Coarsegrained Solils with Fines Content by MLR and GEP, Acta Geotechnica Slovenica, No. 2, (2013), str. 29-41.

[18] Sivrakaya O., Togrol E., Kayadelen C: Estimating Compaction Behavior of Fine-grained Soils Based on Compaction Energy, Can. Geotechnical Journal, Vol. 45, (2008), pp. 877-887.

[19] Sridharan A. and Nagaraj H. B.: Plastic limit and Compaction Characteristics of Fine Grained Soils, Ground Improvement, Vol. 9, Iss. 1 (2005), str. 17-22.

[20] Vukadinović S, Elementi teorije verovatnoće i matematičke statistike, Privredni pregled, Beograd, 1990. 